\title{
Characteristics of violence against women in Campina Grande, north-eastern Brazil
}

LORENA MARQUES NOBREGA', GIGLIANA MARIA SOBRAL CAVALCANTE², ÍTALO DE MACEDO BERNARDINO', ANA FLÁVIA GRANVILLE-GARCIA', EFIGÊNIA FERREIRA FERREIRA ${ }^{2}$ and SERGIO D'AVILA ${ }^{1}$

'Department of Dentistry and Public Health, Paraiba State University, Campina Grande, PB, Brazil

${ }^{2}$ Department of Dentistry and Public Health, Federal University of Minas Gerais, Belo Horizonte, MG, Brazil

\begin{abstract}
Background: Violence against women can have serious consequences, where these victims are affected physically, psychologically, and socially. The aim of this study was to shed light on the sociodemographic characteristics and the characteristics of the conflict suffered by the female victims of violence, who were referred to a forensic medicine and dentistry service in an industrialized city in North-eastern Brazil.

Methods: This study was performed in Campina Grande, Paraiba State (PB), Brazil, involving the analysis of 1704 reports of physical aggression in 2010; 883 reports involving female victims were selected. Sociodemographic data of the victims, circumstances of events, and characteristics of injuries were investigated. Data analysis included descriptive statistics, and chi-square test $(p<0.05)$.

Results: The sample consisted of young women, with mean age of 29.3 years, mostly unmarried, with little education, and mostly not working. The most frequent aggressor was a male known to the victim. The events were mostly a result of non-instrumental aggression, causing multiple injuries. There was statistically significant difference between whether the aggressor was or was not a family member and marital status of the victim ( $p<.001)$, and a significant difference between the use of instrument in the conflict and the presence of facial injuries was found $(p<.001)$. Young women accounted for a high proportion of victims of physical violence. A high percentage of facial traumas was observed.

Conclusion: Given the consequences of such trauma and its prevalence, it is important that future studies be conducted to highlight the risk factors, and to develop policies to combat violence against women.
\end{abstract}

Keywords: violence, women, injury, aggression, Brazil

\section{Introduction}

The term violence against women denotes any act of gender-based violence that results or can result in physical, sexual, emotional, verbal, psychological, and economical abuse, by means including intimidation, harassment, stalking, damage to property, entry into the victim's residence without consent, and other behaviour that attempts to control the victim, coercion or arbitrary deprivation of liberty, whether occurring in public or private (Elsberg et al., 2005; Wood et al., 2008; Moore, 2010).

According to various reports, violence against women has been present for many centuries. However, only towards the second half of the twentieth century, more precisely in the early 1970 , did the topic began to be more prominent in debates, leading to concrete actions taken. Only then were laws dealing with gender violence passed (Testa et al., 2011). A population-based study in Brazil measured the occurrence of violence against women (Venturi et al., 2004), with a nationally representative sample of 2,502 women. It found that $43 \%$ of Brazilian women declared having suffered violence from men in their lifetime and $33 \%, 13 \%$, and $27 \%$ admitted to having suffered some form of physical, sexual, and psychological violence, respectively.

In an attempt to prevent and eradicate violence against women and ensure that legal and police protection are in place to help female victims of aggression, Federal Law No. 11.3040_also known as "Lei Maria da Penha" — was sanctioned in 2006 (Brasil, 2013). It was named in honour of Maria da Penha Maia Fernandes, who fought for 20 years to see her assailant arrested after two homicide attempts. 
The objective of this study was to shed light on the sociodemographic characteristics and the characteristics of the conflict suffered by the female victims of violence, who were referred to a forensic medicine and dentistry service for a corpus delicti examination.

\section{Materials and Methods}

\section{Study area}

This study was conducted in Campina Grande, Brazil, an industrialized city in north-eastern Brazil. The northeast region of Brazil was where the Portuguese colonization began. It is one of the five regions of the country defined by the Brazilian Institute of Geography and Statistics (IBGE). Compared with other regions, it has the third-largest territory and the third largest gross domestic product; it currently has over 49 million inhabitants, which is almost $30 \%$ of the Brazilian population, and is the secondmost-populated region of the country (IBGE, 2014).

\section{Design data collection}

This study employed a retrospective cross-sectional approach and collected the data from the reports of violence victims, both males and females, who sought a forensic medicine and dentistry service for a corpus delicti examination. The reports dated between January and December $2012(n=1,704)$ and completed by the coroner were screened. As this study focuses on only female victims, 883 of the reports were considered for analysis.

\section{Data collection}

Data collection was conducted in a considered one of the main centres of economic development of the Brazilian Northeast. Being one of the main centres of economic development within the region, it is among the $15^{\text {th }}$ most populated cities in the region. It has a population of 379,871 with 182,205 men and 203,008 women, and a human development index of 0.72 (IBGE, 2014).

Data were transcribed from records of police reports to fit the form created for this study. The form has two parts. The first included mainly the sociodemographic information of the victim and the offender (age, gender, marital status, education, occupation, instrument of aggression, gender of the perpetrator, and the relationship between the victim and aggressor). The second concerned information about the event of violence (day of the week, time, location of the assault, and the region of trauma), which was obtained from the technical examination conducted by the expert.

The act of violence was categorized by the level of involvement of the conflict: Extra-familial (perpetrated by individuals other than victim's family members) or intra-familial (perpetrated by partners, ex-partners, and other family members). The type of aggression was also categorized into non-instrumental aggression (when aggression occurred by kicking, punching, slapping, and shoving) or instrumental aggression (for cases where the aggressor was in possession of a firearm, weapon, chemical substances, and others). The age variable was categorized into groups of 10-year intervals until 60 years of age, where those who were 60 and above were collapsed into a single group. Occupations were coded based on the Brazilian Code of Occupations ( $C B O$ ) into their respective sectors of work.

The classification of trauma by Monrovian et al., (2006) was adopted in the characterization of hard tissue trauma (simple and multiple fractures) and that by Manganello-Sousa (2006) was adopted for the characterization of soft tissue injury (laceration, abrasion, and cuts).

\section{Data analysis}

Descriptive statistics of categorical variables were computed using frequency analysis and the mean, standard deviation, and minimum and maximum values were computed for the continuous variable of 
age. Chi-square tests were used for bivariate analyses and when the conditions of the chi-square test were not satisfied, Fisher's exact test was used and the threshold of significance was set at 5\%. In addition, this study followed the STROBE (Strengthening the Reporting of Observational Studies in Epidemiology) guidelines (Von Elm et al., 2008).

\section{Ethical considerations}

The study complied with the ethical standards of international and national human research as set forth by the Helsinki Declaration and Resolution 196/96. In addition, this study was registered under the National System of Research and Ethics (SISNEP) and received ethical approval.

\section{Results}

\section{Demographic characteristic of participants}

The predominant age group of the victims was $20-29$ years (38.4\%) and their mean age was 29.3 years $(S D=12.6$, maximum $=91$, minimum $=0)$. The majority of the victims were women without a partner (62.5\%), had up to eight years of education (45.4\%), and were housewives (21.0\%) (Table 1). There was some missing information in the reports regarding marital status (3.5\%), education (25.2\%), and occupation (9.3\%). This is one of the limitations of this study.

Table 1: Demographic characteristic of victims

\begin{tabular}{|c|c|c|c|}
\hline Variable & Response & Number & Percent \\
\hline & Age (years) & & \\
\hline \multirow[t]{8}{*}{ Age (years } & $<09$ & 17 & 2.0 \\
\hline & $10-19$ & 159 & 18.00 \\
\hline & $20-29$ & 339 & 38.4 \\
\hline & $30-39$ & 205 & 23.2 \\
\hline & $40-49$ & 101 & 11.4 \\
\hline & $50-59$ & 33 & 3.7 \\
\hline & $\geq 60$ & 22 & 2.5 \\
\hline & Unknown & 7 & 0.8 \\
\hline \multirow[t]{3}{*}{ Marital status } & With Partner & 552 & 62.5 \\
\hline & Without Partner & 300 & 34.0 \\
\hline & Unknown & 31 & $3 \cdot 5$ \\
\hline \multirow[t]{5}{*}{ Education } & Illiterate & 37 & 4.2 \\
\hline & Up to 08 years of schooling & 401 & $45 \cdot 4$ \\
\hline & Up to 11 years of schooling & 155 & 17.6 \\
\hline & Higher education & 67 & 7.6 \\
\hline & Unknown & 223 & 25.2 \\
\hline \multirow[t]{7}{*}{ Occupation } & Administration/Management & 83 & 9.4 \\
\hline & Worker services & 135 & $15 \cdot 3$ \\
\hline & Home & 185 & 21.0 \\
\hline & Farmer & 102 & 11.5 \\
\hline & Student & 173 & 19.6 \\
\hline & Others & 205 & 23.2 \\
\hline & Total & 883 & 100 \\
\hline
\end{tabular}

Majority of the victims were housewives (21.0\%, worker services (15.3\%)and students (19.6\%). The group of others (23.2\%) included industrial/construction (14), Government employee (15), informal (25), retired (22), professional at medium and upper level (47) and those whose occupations were unknown (82). 
Characteristics of the conflicts, aggressor and event of aggression

Most of the cases involved an aggressor outside the family circle (66.7\%), and $59.2 \%$ of the aggressors were males and $40.4 \%$ of them knew the victim (Table 2 ).

Table 2: Distribution of characteristics of the conflicts and the aggressor

\begin{tabular}{llll}
\hline Variable & Response & Number & Percent \\
\hline Conflict involvement level & Intra-familial & 272 & 30.8 \\
& Extra-familial & 589 & 66.7 \\
& Unknown & 22 & 2.5 \\
Sex of the offender & Male & 303 & 34.3 \\
& Female & 523 & 59.2 \\
& Male and female & 22 & 2.5 \\
Relationship with victim & Unknown & 35 & 4.0 \\
& Partner & 202 & 22.9 \\
& Ex-partner & 124 & 14.0 \\
& Familial & 99 & 11.2 \\
& Known & 357 & 40.4 \\
Total & Strangers & 67 & 7.6 \\
& Unknown & 34 & 3.9 \\
\hline
\end{tabular}

Most of the attacks were a form of non-instrumental aggression (83.6\%), occurred predominantly during the day (48.6\%), and more frequently took place on a Sunday (18.8\%) than any other day of the week (Table 3).

Table 3: Distribution of characteristics of the event of aggression

\begin{tabular}{llll}
\hline Variable & Response & Number & Percent \\
\hline Mechanism of aggression & Instrumental * & 129 & 14.6 \\
& Non-instrumental & 738 & 83.6 \\
& Unknown & 16 & 1.8 \\
Time of aggression & Day (06:00 to 17:59) & 429 & 48.6 \\
& Night (18:00 to 05:59) & 395 & 44.7 \\
Day of aggression & Unknown & 59 & 6.7 \\
& Monday & 127 & 14.4 \\
& Tuesday & 136 & 15.4 \\
& Wednesday & 124 & 14.0 \\
& Thursday & 106 & 12.0 \\
Total & Friday & 105 & 11.9 \\
& Saturday & 106 & 12.0 \\
\hline
\end{tabular}

*Injuries caused by gunshot, knives, chemical substances, etc., were included in the instrumental category

\section{Distribution of characterization of injury}

In addition, $96.9 \%$ of the victims sustained soft tissue injuries and $51.6 \%$ of them suffered injuries in more than one region of the body. The facial injuries sustained by the victims were mostly at multiple regions (50.0\%), with the orbital region (20.1\%) the next most common location (Table 4 ). 
Table 4: Distribution of characterization of injury $(\mathrm{N}=883)$

\begin{tabular}{llll}
\hline Variable & & Number & Percent \\
\hline Type of trauma & Soft tissue & 856 & 96.9 \\
& Hard tissue & 25 & 2.8 \\
Body region & Unknown & 2 & 0.3 \\
& Head & 195 & 22.1 \\
& Neck & 14 & 1.6 \\
& Upper limb & 139 & 15.7 \\
Facial region & Lower limb & 38 & 4.3 \\
& Chest & 41 & 4.7 \\
& More than one region & 456 & 51.6 \\
& Front & 26 & 6.4 \\
& Nasal & 17 & 4.1 \\
& Orbital & 82 & 20.1 \\
& Zygomatic & 13 & 3.2 \\
& Mandibular & 4 & 1.0 \\
& Chin & 2 & 0.5 \\
& Masseter & 13 & 3.2 \\
& Oral & 47 & 11.5 \\
& More than one region & 204 & 50.0 \\
\hline
\end{tabular}

Association of the level of conflict involvement and the victim's marital status Analysis of the relationship between the level of conflict involvement and the victim's marital status no partner had yielded a significant difference $(p<0.001)$ (Table 5$)$.

Table 5: Association of the level of conflict involvement and the victim's marital status

$$
\text { Level of conflict involvement }
$$

\begin{tabular}{|c|c|c|c|c|c|c|c|}
\hline \multirow[t]{2}{*}{ Variable } & \multicolumn{2}{|c|}{$\begin{array}{l}\text { Members } \\
\text { the family group }\end{array}$} & \multicolumn{2}{|c|}{$\begin{array}{l}\text { Members outside the } \\
\text { family group }\end{array}$} & \multicolumn{2}{|l|}{ Total } & \multirow[t]{2}{*}{$P$-value } \\
\hline & $\mathbf{n}$ & $\%$ & $\mathbf{n}$ & $\%$ & $\mathbf{N}$ & $\%$ & \\
\hline \multicolumn{8}{|l|}{ Marital status } \\
\hline No partner & 121 & 45,2 & 419 & 74,2 & 540 & 64,8 & $p^{(1)}<.001^{*}$ \\
\hline With partner & 147 & 54,8 & 146 & 25,8 & 293 & 35,2 & \\
\hline Total $^{(2)}$ & 268 & 100.0 & 565 & 100.0 & 833 & 100 & \\
\hline
\end{tabular}

(*): Significant difference at 5.0\%; (1): Pearson chi-square test

Association of the use of instrument during conflict and facial injury

The presence of facial lesions was also affected by the use of instrument by the offender $(p<.001)$, had yielded a significant difference, as shown in Table 6.

Table 6: Association of the use of instrument during conflict and facial injury

\begin{tabular}{llllllll}
\hline Variable & \multicolumn{2}{l}{ No instrument } & \multicolumn{2}{l}{ With instrument } & \multicolumn{2}{c}{ TOTAL } & \multicolumn{2}{c}{ P-value } \\
& $\mathbf{n}$ & $\%$ & $\mathbf{n}$ & $\%$ & $\mathbf{N}$ & $\%$ & \\
\hline Facial injury & & & & & & & $p^{(1)}<.001^{*}$ \\
Present & 362 & 49,0 & 41 & 31,8 & 403 & 46,5 & \\
Absent & 376 & 51,0 & 88 & 68,2 & 464 & 53,5 & \\
& & & & & & & \\
Total $^{(2)}$ & $\mathbf{7 3 8}$ & $\mathbf{1 0 0 . 0}$ & $\mathbf{1 2 9}$ & $\mathbf{1 0 0 . 0}$ & $\mathbf{8 6 7}$ & $\mathbf{1 0 0}$ \\
\hline
\end{tabular}

(*): Significant difference at 5.0\%; (1): Pearson chi-square test 


\section{Discussion}

This epidemiological study presents the first profiling of violence against women in north-eastern Brazil. In Brazil, most of this information on violence against women was based on mortality statistics, police reports, reports from the justice system, and mainly statistics of victims served by the healthcare system. The use of such data could have led to underestimation of the magnitude of the issue and its impact on the population. It is important to emphasize the difference between the current study and that employing hospitalization information. As hospitalization is associated with more severe cases, hospital data would provide a different kind of profiling, as there is a stark contrast between the institutions that provided the data for the present and previous research. Forensic medicine and dentistry services cover a greater variety of cases that involve violation of physical integrity and even injuries that can become life threatening. Therefore, such services are a rich source of data that captures injuries of varying severity, including events not within the scope of hospitals.

Women who were assaulted sought two types of service after the acts of aggression: hospital services for health restoration and forensic services, in search of legal assistance and restoration of their physical integrity. The inspector in charge of the investigation then directs the victim to the Medical and Dental Centres for a forensic examination to establish corpus delicti, which is necessary evidence to support legal and judicial prosecution and conviction of the perpetrator (Brasil, 2013).

Global statistics indicate a high prevalence of violence against women (Krug et al., 2002). In addition, a study conducted across 10 countries has shown that the rates of physical (12.9-61.0\%), sexual (6.2-58.6\%), and psychological violence (19.6-75.1\%) perpetrated by intimate partners are relatively high (Garcia-Moreno et al., 2005). In Latin America and the Caribbean, approximately onethird of women has been the victim of sexual, physical, or psychological violence throughout her lifetime (Organización Panamericana de la Salud, 2007).

In this study, most victims were between 20 to 29 years, which was similar to findings from other studies that highlighted young adults as the predominant victims of violence (Frank et al., 2010; Gómez-Dantés et al., 2006; Hashemi et al., 2011; Saddki et al., 2010; Vives-Cases et al., 2011; Caldas et al., 2012). The current study also found similar trends of decreasing level of violence with increasing age of victim, as in the study by Le Franc et al. (2008). In contrast to some studies (Frank et al., 2010; Saddki et al., 2010; Vives-Cases et al., 2011; Caldas et al., 2012; Le Franc et al., 2008; Krebs et al., 2011), most of the victims in the current study were single. The significant number of unmarried women as victims of violence was an unexpected finding that raised some questions regarding the data collected from the reports. However, it is likely that these unmarried women declared their status as single despite having a cohabiting relationship with their partners.

The different ways of categorizing the victims' education level made comparison with other studies difficult. However, it was apparent that victims of the present study seemed to have low levels of education (Gómez-Dantés et al., 2006; Vives-Cases et al., 2011). In this study, as 45.4\% of the victims had lesser than eight years of education. Low levels of education among victims reflected lower incomes. This, among other factors, could determine the victim's financial dependency of her partner, lead to a stronger the emotional connection with the partner and more unwillingness to denounce the relationship, and compel "silent acceptance" of violence. Vives-Cases et al. (2011) found that most female victims of violence were not employed, similar to what this study had realized, where a high proportion of women were housewives. Adeodato et al. (2005) proposed that women with paid jobs were financially independent from their aggressors, and this led them to be less tolerant toward aggressive behaviors, since they also tended to be more informed about their rights.

Consistent with the literature, the majority of aggressors were male (59.2\%) and known to the victim (40.4\%) (Frank et al., 2010; Silva et al., 2010). Most of the events of aggression were carried out 
by members outside the family group (66.7\%), and a significant proportion of the aggressors were the victims' intimate partner (22.9\%) (Frank et al., 2010; Silva et al., 2010; Caldas et al., 2012).

Identifying violence against women remains a challenge. In many instances, such violence leaves no visible evidence and the victims suffer in silence. When the injuries become apparent, it is a warning signal. Healthcare professionals who come into contact with them must be equipped with the knowledge to evaluate the situation and refer the victims to specialized services of care for victims of aggression. Non-instrumental aggression (83.6\%) refers to acts of violence that do not involve the use of instruments, for example, shoving, slapping, and kicking, and was the most prevalent form of aggression in this study, supporting the findings of Caldas et al., (2012). Aggression took place most frequently on weekends (30.8\%), in accordance with other studies (Eggensperger et al., 2007; Mallikarjuna et al., 2009). It occurred a little more frequently during the day (48.6\%) than at night (44.7\%). Alcohol is a known depressant that affects the central nervous system, resulting in increased feelings of trust and confidence in abilities but reduced coordination. These physiological effects may explain the increased occurrence of interpersonal violence, as reported in several studies (Eggensperger et al., 2007; Bergh et al., 2012; Hogg et al., 2000).

In terms of the area of body with injuries, the majority of the victims had multiple injuries, confirming the results of Caldas et al., (2012). The face was the second-most injury-inflicted region. These lesions are more frequently in the soft tissue (Saddki et al., 2010; Caldas et al., 2012). The head and face were the most common sites of injury. This can be explained by the head's prominent location and its exposure and lack of protection. Moreover, the aesthetic value of the face to women makes it the primary target of attack in an attempt to intimidate and humiliate the victims. The upper limbs were also among the most affected areas of the body, since they could be used for self-defense, in protecting and minimizing injuries resulting from the conflicts. The most common facial injuries involved the orbital region, as in other studies (Caldas et al., 2012; Arosarena et al., 2009). In the study by Saddki et al., (2010), injuries were found most frequently in the middle third of the face and less often in the upper third or lower third of the face.

One limitation of the study was the presence of missing data due to incomplete filling up of the reports. It is also noteworthy that in many situations, the professionals responsible for the care of the victims were not prepared to work in this function (Rezende et al., 2007). In addition, the lack of professional psychologists in victim assistance services, to help them better relate what actually happened, makes it difficult to accurately understand the influence of cultural and psychological barriers in these reports (Bradley et al., 2002). It is also important to note that the data from this study were limited to morbidity. Furthermore, due to the cross-sectional design, results not only demonstrate causal associations. Thus, caution is needed when analysing the data. Longitudinal studies are needed to further understanding of the factors related to the occurrence of facial trauma in victims of violence against women.

Dentists who work in emergency services are part of the team responsible for the primary health care of victims and are obliged to intervene in situations involving violence. Changes are needed at the national level, within the education and public health systems, to train professionals in identifying cases of aggression and prioritize intervention for the victims (Hendler et al., 2007).

The majority of abused women in this study were young, without partners, with little education, and housewives who were financially dependent on other people. Therefore, being economically and socially disadvantaged made this group vulnerable to aggressive behaviors. The use of an instrument during the act of aggression is associated with the occurrence of facial injuries, with lesions located predominantly in the soft tissue, and multiple injuries. Given the consequences and prevalence of such trauma, studies must examine the profile of at-risk populations and understand their experiences in combating violence against women, since such violence is known to be preventable. 


\section{Conflict of interest}

The authors have no conflict of interest in connection with this article.

\section{Acknowledgments}

The authors are grateful to the Forensic Medicine and Dentistry Centre at which this study was conducted. Funding from the Brazilian fostering agencies Conselho Nacional de Pesquisa and Fundação de Apoio à Pesquisa do Estado da Paraíba.

\section{References}

Adeodato, V.G., Carvalho, R.R., Siqueira, V.R., \& Souza, F.G.M. (2005) Quality of life and depression in women abused by their partners. Revista Saude Publica 39, 108-113.

Arosarena, O.A., Fritsch, T.A., Hsueh, Y., Aynehchi, B., \& Haug, R. (2009) Maxillofacial injuries and violence against women. Archives of Facial Plastic Surgery 11, 48-52.

Bergh, B.V.D., Karagozoglu, K.H., Heymans, M.W. \& Forouzanfar, T. (2012) A etiology and incidence of maxillofacial trauma in Amsterdam: A retrospective analysis of 579 patients. Journal of Craniomaxillofacial Surgery 40, 165-169.

Bradley, F., Smith, M., Long, J., \& O'Dowd, T. (2002) Reported frequency of domestic violence: cross sectional survey of women attending general practice. BMJ 324, 271.

Brasil. Ministério da Saúde, Secretaria Especial de Política para as mulheres, Law n. 11.340 [Internet]. Brasilia: [updated 2006 Aug 23; cited 2013 nov 18]. Available from: http://spm.gov.br/publicacoes-teste/publicacoes/2011/politica-nacional.

Brasil. Presidência da República. Secretaria Especial de Políticas para as Mulheres. Política Nacional de enfrentamento à Violência contra a mulher. [Internet]. Brasilia: [ cited $2013 \mathrm{dec} 22$ ]. Available from: http://www.campanhapontofinal.com.br/download/informativo_03.pdf

Caldas, I.M., Grams, A.C., Afonso, A., \& Magalhães, T. (2012) Oral injuries in victims involving intimate partner violence. Forensic Science International 221, 102-105.

Eggensperger, N., Smolka, K., Scheidegger, B., Zimmermann, H., \& Lizuka, T. (2007) A 3-year survey of assault-related maxillofacial fractures in central Switzerland. Journal of Craniomaxillofacial Surgery 35, 161-167.

Elsberg, M., \& Heise, L. (2005) Researching violence against women: A practical guide for researches and activists. Washington DC: World Health Organization, PATH.

Frank, S., Coelho, E.B., \& Boing, A.F. (2010) Perfil dos estudos sobre violência contra a mulher por parceiro íntimo: 2003 a 2007. Revista Panamericana de Salud Publica 27, 376-381.

Garcia-Moreno, C., Jansen, H.A., Ellsberg, M., Heise, L., \& Watts, C. (2005) WHO multi-country study on women's health and domestic violence against women: initial results on prevalence, health outcomes and women's responses. Geneva: World Health Organization.

Gómez-Dantés, H., Vázques-Martínez, J.L., \& Fernández-Cantóon, S.B. (2006) La violência em las mujere usuárias de los serviços de salud em el IMSS y la SSA. Salud Publica de Mexico 48, 279287.

Hashemi, H.M., \& Beshkar, M. (2011) The prevalence of maxillofacial fractures due to domestic violence - a retrospective study in a hospital in Tehran, Iran. Dental Traumatology 27, 385-8.

Hendler, T.J., \& Sutherland, S.E. (2007) Domestic violence and its relation to dentistry: A call for change in Canadian Dental Pratice. Journal of Canadian Dental Association 73: 617. 
Hogg, N.J., Stewart, T.C., Armstrong, J.E., \& Girotti, M.J. (2000) Epidemiology of maxillofacial injuries at trauma hospitals in Ontario, Canada, between 1992 and 1997. Journal of Trauma 49, 425432.

Instituto Brasileiro de Geografia e Estatística [IBGE], [Internet]. Brasilia: [cited 2014 Jan 12]. Available from: http://www.ibge.gov.br/cidadesat/\#.

Krebs, C., Breiding, M.J., Browne, A., \& Warner, T. (2011) The association between different types of intimate partner violence experienced by women. Journal of Family Violence 26, 487-500.

Krug, E.G., Dahlberg, L.L., Mercy, J.A., Zwi, A.B., \& Lozano, R. (2002) World report on violence and health. Geneva: World Health Organization.

Le Franc, E., Samms-Vaughan, M., Hambleton, I., Fox, K., \& Brown, D. (2008) Interpersonal violence in three Caribbean coutries: Barbados, Jamaica and Trinidad and Tobago. Revista Panamericana de Salud Publica 24, 409-421.

Mallikarjuna, S.K., \& Krishnappa, P. (2009) Prevalence of maxillofacial injuries by motorized two wheeler road traffic accidents in Bangalore city. Dental Traumatology 25, 599-604.

Manganello-Sousa, L.C. (2006) Trauma das partes moles: princípios de tratamento dos ferimentos cutaneous. In: Manganello-Sousa LC, Luz JGC. Tratamento cirúrgico do trauma bucomaxilofacial, 3rd ed. São Paulo: Roca, 75-85.

Montovani, J.C., Campos, L.M.P., Gomes, M.A., Moraes, V.R.S., Ferreira, F.D. \& Nogueira E.A. (2006) Etiology and incidence facial fractures in children and adults. Revista Brasileira Otorrinolaringologia 72, 235-241.

Moore, A.J. (2010) Endangered species: Examining South Africa's national rape crisis and its legislative attempt to protect its most vulnerable citizens. Vanderbilt Law Review 28, 1469-1498.

Organización Panamericana de la Salud. Health in the Americas. Washington DC: Scientific and Technical Publication No. 622 - OPAS; 2007.

Rezende, E.J.C., Araújo, T.M., Moraes, M.A.S., Santana, J.S.S., \& Radicchi. R. (2007) Mouth-dental injuries in women violence victims: a pilot study of registered cases in the Legal Medical Institute of Belo Horizonte, MG. Revista Brasiliera de Epidemiologia 10, 202-214.

Saddki, N., Suhaimi, A.A., \& Daud, R. (2010) Maxillofacial injuries associated with intimate partner violence in women. BMC Public Health 10: 268.

Silva, M.A., Falbo-Neto, G.H., Figueiroa, J.N., \& Cabral-Filho, J.E. (2010) Violence against women: prevalence and associated factors in patients attending a public healthcare service in the Northeast of Brazil. Cadernos de Saude Publica 26, 264-272.

Testa, M., Livingston, J.A., \& VanZile-Tamsen, C. (2011) Advancing the study of violence against women using mixed methods: integrating qualitative methods into a quantitative research program. Violence Against Women 17, 236-250.

Venturi, G., Recamán, M., \& Oliveira, M. (2004) A mulher brasileira nos espaços público e privado. São Paulo: Fundação Perseu Abramo.

Vives-Cases, C., Ruiz-Cantero, M.T., Escriba-Aguir, V., \& Miralles, J.J. (2011) The effect of intimate partner violence and other forms of violence against women on health. Journal of Public Health 33, $15-21$.

Von Elm, E., Altman, D.G., Egger, M., Pocock, S.J., Gotzsche, P.C., \& Vandenbroucke, J.P. (2008) The Strengthening the Reporting of Observational Studies in Epidemiology (STROBE) statement: guidelines for reporting observational studies. Journal of Clinical Epidemiology 61, 344-349.

Wood, K., Lambert, H. \& Jewkes, R. (2008) Injuries are beyond love: Physical violence in young South Africans' sexual relationships. Medical Anthropology 27, 43-69. 